\title{
Common Process Extraction pada Model Proses Bisnis Tebang Muat Angkut (TMA)
}

\author{
Salma Fatia \\ Jurusan Teknik Informatika \\ Universitas Islam Negeri Maulana \\ Malik Ibrahim \\ Malang, Indonesia \\ 17650017@student.uin-malang.ac.id
}

\author{
Muhammad Ainul Yaqin \\ Jurusan Teknik Informatika \\ Universitas Islam Negeri Maulana \\ Malik Ibrahim \\ Malang, Indonesia \\ yaqinov@ ti.uin-malang.ac.id
}

\author{
Adi Heru Utomo \\ Jurusan Teknologi Informasi \\ Politeknik Negeri Jember \\ Jember, Indonesia \\ adiheruutomo@polije.ac.id
}

\begin{abstract}
In an organizational environment, there are various business process models with the same procedures. If an organization builds a system with the same procedure repeatedly, it will undoubtedly incur a lot of effort and money. Therefore, it is necessary to extract common fragments to save effort. This research uses four scenarios of business process models: sequence, branching, nested branching, and looping. This study uses Business Process Modeling Notation (BPMN) notation so that the process model consists of activities, connectors, and gateways. Structural similarity is measured using the Jaccard similarity formula by comparing the process model. The similarity of behavior is measured using the Transition Adjacency Relations (TARs) method to obtain common fragments. The results show that the sequence process model will produce a common fragment that tends to be sequential too. The branching will produce a common fragment that tends to branch, and nested branching will produce a common fragment that tends to be branched and nested, as well as looping will produce a common fragment contains looping too. The experimental results show that the proposed method can extract common fragments based on the available business process models.
\end{abstract} TARs

Keywords—BPMN; common fragment; behavioral similarity;

Abstrak - Dalam lingkungan organisasi, terdapat berbagai model proses bisnis dengan prosedur yang sama. Jika suatu organisasi membangun sistem dengan prosedur yang sama secara berulang-ulang, niscaya akan mengeluarkan banyak tenaga dan biaya. Oleh karena itu, perlu mengekstrak fragmen umum untuk menghemat tenaga. Penelitian ini menggunakan empat skenario model proses bisnis yaitu sequence, branching, nested branching, dan looping. Penelitian ini menggunakan notasi Business Process Modeling Notation (BPMN) sehingga model proses terdiri dari aktivitas, konektor, dan gateway. Kemiripan struktural diukur menggunakan rumus kemiripan Jaccard dengan membandingkan model proses. Kesamaan perilaku diukur menggunakan metode Transition Adjacency Relations (TARs) untuk mendapatkan fragmen yang sama. Hasil penelitian menunjukkan bahwa model sequence process akan menghasilkan common fragment yang cenderung berurutan juga. Percabangan akan menghasilkan fragmen umum yang cenderung bercabang, dan percabangan bersarang akan menghasilkan fragmen umum yang cenderung bercabang dan bersarang, serta perulangan akan menghasilkan fragmen umum yang berisi perulangan juga. Hasil eksperimen menunjukkan bahwa metode yang diusulkan dapat mengekstrak fragmen umum berdasarkan model proses bisnis yang tersedia. TARs

Keywords-BPMN; common fragment; kemiripan perilaku;

\begin{abstract}
Setiap organisasi menerapkan prosedur yang bervariasi dalam menjalankan proses bisnisnya. Ada kalanya prosedur yang digunakan antara satu organisasi dan organisasi yang lain sama, namun juga tidak jarang menggunakan prosedur yang berbeda. Apabila organisasi membangun sistem dengan prosedur sama berulang kali, tentunya akan mengeluarkan banyak usaha dan biaya.
\end{abstract}

PENDAHULUAN

Dengan adanya beberapa variasi dalam proses bisnis, diperlukan pengukuran model proses agar dapat diketahui standar proses bisnis di setiap alur dan dapat meminimalisir adanya duplikasi proses bisnis tersebut. Salah satu cara yang dapat dilakukan adalah dengan mengekstraksi common fragment. Common fragment dapat didefinisikan sebagai bagian umum dari beberapa proses bisnis yang saling terkait. Fleksibilitas common fragment suatu proses bisnis dapat divariasikan sesuai kebutuhan dari suatu organisasi [1].

Pemodelan proses bisnis merupakan diagram yang umum mewakili urutan kegiatan dengan menunjukkan peristiwa, tindakan, dan hubungan atau titik-titik koneksi secara berurutan dari titik awal hingga titik akhir. Proses bisnis dapat dimodelkan ke dalam beberapa notasi seperti, UML Activity Diagram, Business Process Modeling Notation (BPMN), Event-Driven Process Chain (EPC), dan Petri Net Modeling Notation (PNML). BPMN menyediakan notasi yang dapat dengan mudah dipahami oleh semua pengguna bisnis. Salah satu cara untuk menganalisis model BPMN tersebut adalah dengan menghitung kemiripannya.

Pada penelitian sebelumnya, telah dilakukan pengukuran kemiripan model proses bisnis. Penelitian terkait sistem cerdas untuk menemukan behavioral similarity pada model proses bisnis menggunakan algoritma Transition Adjacency Relations, kemudian mengelompokkan proses bisnis sesuai hasil perhitungan kemiripan berdasarkan nilai clustering serta membentuk common fragment [2]. Penelitian lain menentukan kemiripan semantic [3], structural, dan behavioral dengan menentukan bobot kemiripan dan nilai batas cluster dengan menggunakan nilai uji coba dan model proses PNML [4].

Dalam penelitian ini, peneliti menggunakan empat skenario model proses Tebang Muat Angkut (TMA) yang berbeda untuk dianalisis setiap fragmennya. Skenario terdiri dari model proses cenderung sequence, bercabang, bercabang tersarang, dan perulangan. Model proses menggunakan notasi BPMN, sehingga bagian model terdiri dari activity, connector, dan gateway [5]. Kemiripan struktural diukur menggunakan algoritma Jaccard Coefficient Similarity untuk mendapatkan nilai similaritas 
dari struktur model proses yang dibandingkan [6]. Selanjutnya untuk mendapatkan common fragment dilakukan pengukuran similaritas perilaku menggunakan algoritma Transition Adjacency Relations (TARs). Kemudian dilakukan perhitungan kompleksitas pada hasil common fragment dan model proses awal menggunakan Yaqin complexity untuk mengetahui persentase penyusutan kompleksitasnya.

\section{METODE PENELITIAN}

Metodologi penelitian yang diimplementasikan terbagi ke dalam beberapa tahapan, ditunjukkan dengan kerangka konseptual pada Gambar 1.

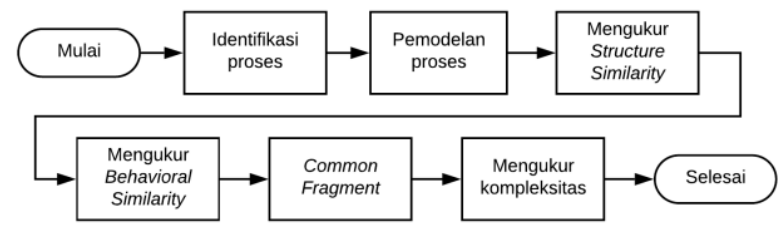

Gambar 1. Kerangka Konseptual Penelitian

Dalam penelitian ini, peneliti menggunakan notasi BPMN dengan empat skenario model proses Tebang Muat Angkut (TMA) yang terdiri dari model proses sequence, percabangan, percabangan tersarang dan perulangan. Adapun contoh model proses yang digunakan, sebagai berikut :

\section{Skenario 1: Cenderung Sequence}

Pada skenario 1, model proses TMA yang ditampilkan cenderung sequence atau hanya memiliki satu percabangan. Proses yang terjadi juga sederhana dan tidak memiliki proses perulangan. Skenario 1 diusulkan untuk mengetahui pengaruh model proses secara sequence terhadap kemiripan struktur dan perilaku untuk mengetahui hasil common fragment yang didapat. Berikut 3 model proses untuk skenario 1:

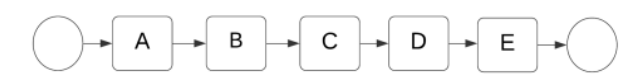

(a)

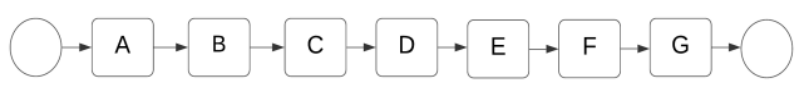

(b)

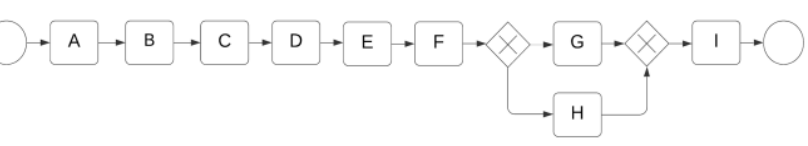

(c)

Gambar. 1.Model Proses Cenderung Sequence

\section{Skenario 2: Percabangan}

Pada skenario 2, model proses TMA yang ditampilkan cenderung bercabang atau memiliki lebih dari satu percabangan. Skenario 2 diusulkan untuk mengetahui pengaruh model proses secara bercabang terhadap kemiripan struktur dan perilaku untuk mengetahui hasil common fragment yang didapat. Berikut 3 model proses untuk skenario 2:

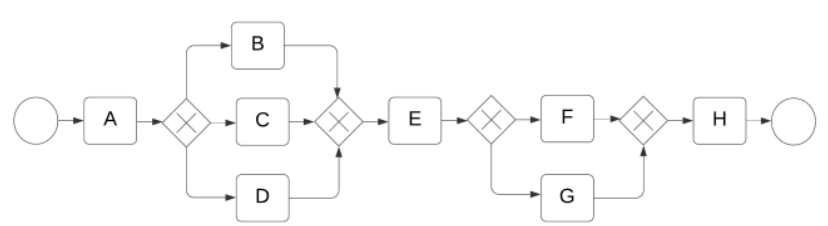

(a)

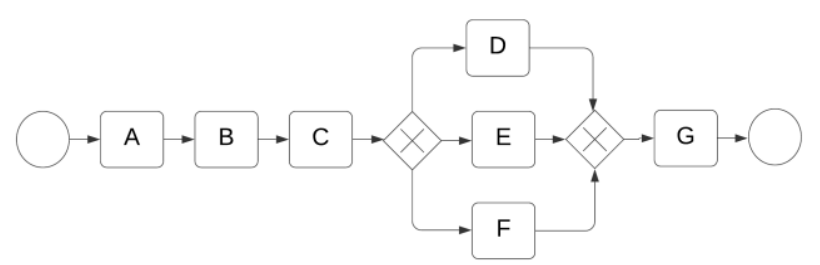

(b)

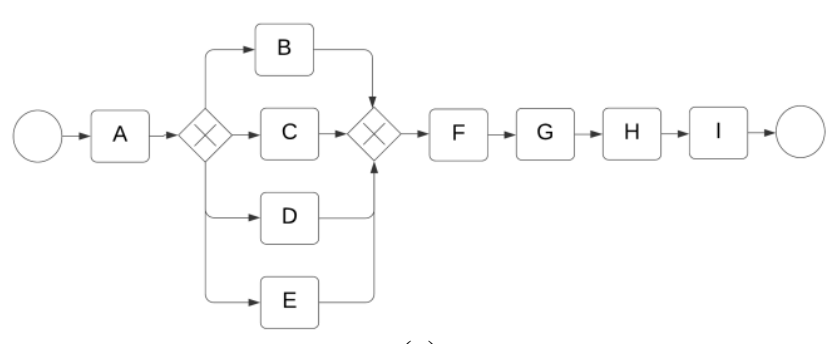

(c)

Gambar. 2.Model Proses Percabangan

Skenario 3: Percabangan Tersarang

Pada skenario 3, model proses TMA yang ditampilkan cenderung bercabang tersarang atau memiliki lebih dari satu percabangan dan dalam percabangan tersebut terdapat percabangan lagi. Skenario 3 diusulkan untuk mengetahui pengaruh model proses secara bercabang tersarang terhadap kemiripan struktur dan perilaku untuk mengetahui hasil common fragment yang didapat. Berikut 3 model proses untuk skenario 3 :

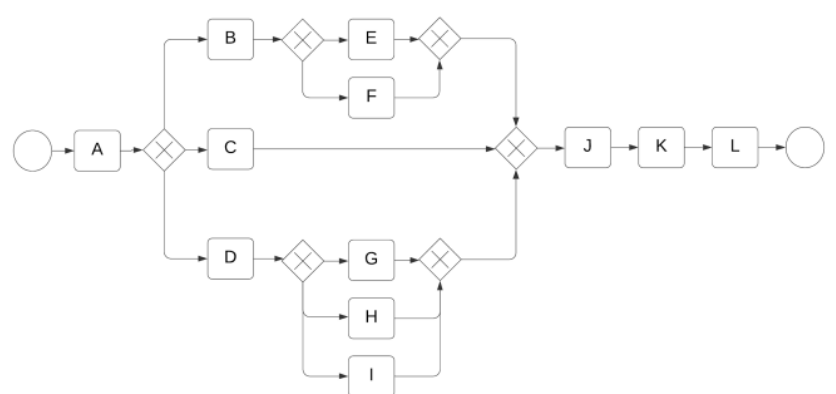

(a)

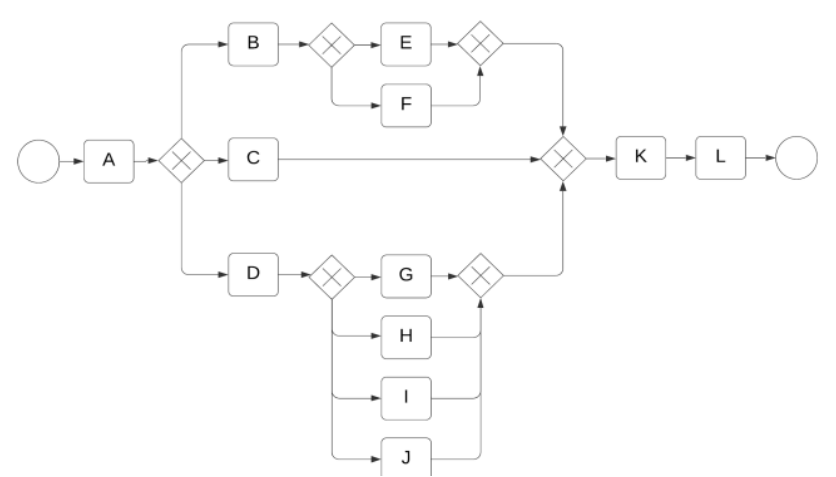

(b) 


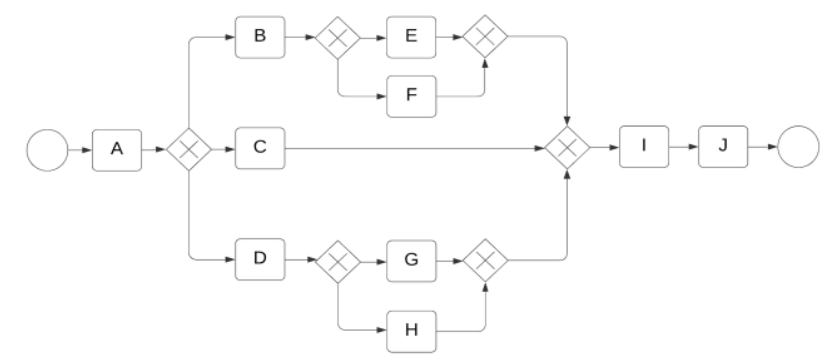

(c)

Gambar. 3.Model Proses Percabangan Tersarang

Skenario 4: Perulangan

Pada skenario 4, model proses TMA yang ditampilkan terdapat proses perulangan. Skenario 4 diusulkan untuk mengetahui pengaruh model proses perulangan terhadap kemiripan struktur dan perilaku untuk mengetahui hasil common fragment yang didapat. Berikut 3 model proses untuk skenario 4:

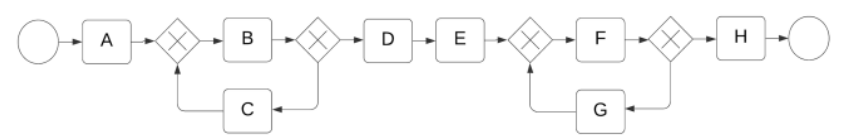

(a)

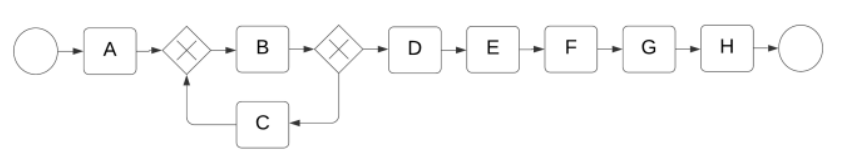

(b)

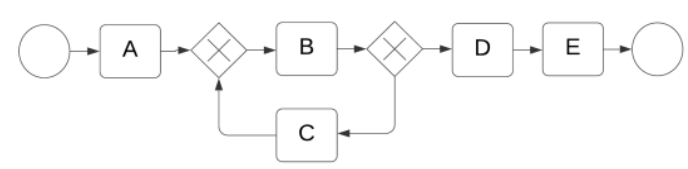

(c)

Gambar. 4.Model Proses Perulangan

keterangan dari empat skenario model proses TMA diuraikan pada tabel 1 berikut.

TABEL I. Keterangan Model Proses

\begin{tabular}{|l|l|}
\hline \multicolumn{2}{|c|}{ Keterangan } \\
\hline A = tebang & G = pakai_grabLoader \\
B = proses_manual & $\mathrm{H}=$ pakai_caneHarvester \\
C = proses_semiMekanik & $\mathrm{I}=$ pakai_greenCane \\
D = proses_mekanik & $\mathrm{J}=$ pakai_chopper \\
E = pakai_sabit & $\mathrm{K}=$ muat \\
F = pakai_clurit & L = angkut_kePabrik \\
\hline
\end{tabular}

Nilai kesamaan pada kemiripan struktur diukur dengan membandingkan aspek yang serupa pada model proses BPMN, seperti label task activity, connector, dan gateway (percabangan) yang sama. Model proses secara struktural dihitung kemiripannya menggunakan rumus Jaccard Coefficient Similarity pada (1).

$$
\text { Jacc } \operatorname{sim}=\frac{|x \cap y|}{|x \cup y|}
$$

Kemudian, untuk mendapatkan common fragment diukur kesamaan perilaku dari model proses menggunakan algoritma Transition Adjacency Relations (TARs). TARs merupakan relasi aktivitas yang dapat diartikan sebagai urutan eksekusi yang diperoleh dari hubungan antar aktivitas yang ada berdasarkan relasi transisi yang berdekatan.

Common fragment yang diekstrak pada setiap skenario model proses bisnis ditentukan dengan mengukur kemiripan beberapa model proses dan menghasilkan bagian yang sama pada masing-masing skenario. Berikut langkah-langkah mengukur kesamaan perilaku menggunakan TARs:

1. Ambil nilai transisi dari model 1 dan model 2

2. Gabungkan dua nilai transisi terdekat secara berurutan pada model 1 dan model 2. Hasilnya disebut TARset

3. Hitung jumlah TARset model 1 dan TARset model 2

4. Bandingkan model TARset 1 dan model TARset 2

5. Hitung jumlah similar TARset antara model 1 dan model 2

6. Hitung nilai yang sama menggunakan jumlah TArset yang sama dibagi jumlah model TARset 1 dikalikan dengan jumlah model TARset 2

Nilai kemiripan perilaku menggunakan algoritma TARs dapat dihitung dengan (2).

$$
\operatorname{sim} B=\frac{(\text { Amount of Similar TARset })^{2}}{\text { TARset model } 1 \times \text { TARset model } 2}
$$

Selanjutnya, setelah ditemukan common fragment pada setiap skenario model proses maka dilakukan perhitungan kompleksitas menggunakan rumus Yaqin complexity yang ditunjukkan pada (3). Rumus Yaqin complexity lebih komprehensif dan lebih sensitif terhadap perubahan kecil pada struktur model proses bisnis [7].

$$
Y C=N s+A s+C A N D+C X O R+C O R+C c y c+C D
$$

Berikut adalah penjelasan dari aspek-aspek yang digunakan dalam rumus Yaqin complexity:

$$
\begin{array}{ll}
\mathrm{N}_{\mathrm{s}} & =\text { Jumlah node } \\
\mathrm{A}_{\mathrm{s}} & =\text { Aspek kegiatan (activity) } \\
\mathrm{CAND} & =\text { Kompleksitas percabangan AND } \\
\mathrm{CXOR} & =\text { Kompleksitas percabangan XOR } \\
\mathrm{COR} & =\text { Kompleksitas percabangan OR } \\
\mathrm{C}_{\mathrm{CYC}} & =\text { Kompleksitas perulangan } \\
\mathrm{CD} & =\text { Kompleksitas kedalaman (depth) }
\end{array}
$$

\section{HASIL DAN PEMBAHASAN}

Pada bagian ini, peneliti menggunakan skenario model 3 yakni percabangan tersarang untuk diukur kemiripan strukturalnya. Pengukuran dilakukan dengan membandingkan terlebih dahulu model 3A dan 3B, kemudian 3A dan 3C, serta terakhir 3B dan 3C. Notasi BPMN terdiri dari activity, connector, dan gateway sehingga dari perbandingan model $3 \mathrm{~A}$ dan $3 \mathrm{~B}$ didapatkan irisan elemen sebagai berikut :

$\begin{array}{ll}\text { label task activity } & =13 \\ \text { connector } & =23 \\ \text { gateway } & =6\end{array}$


Sedangkan, gabungan dari kedua model, yakni :

$\begin{array}{ll}\text { label task activity } & =15 \\ \text { connector } & =26 \\ \text { gateway } & =6\end{array}$

Angka-angka yang telah didapatkan dimasukkan ke dalam rumus perhitungan kemiripan pada (1).

$$
\text { Jacc } \operatorname{sim}=\frac{13+23+6}{15+26+6}=\frac{42}{47}=0.89
$$

Menggunakan langkah yang sama kemudian dibandingkan model selanjutnya yaitu, 3A dan 3C, serta 3B dan $3 \mathrm{C}$. Ketiga elemen pada masing-masing model BPMN dihitung kemudian dibandingkan dengan model BPMN lainnya menggunakan nilai kemiripan struktural antara dua model yang ditetapkan pada interval 0 sampai 1 [8]. Berikut hasil perhitungan kemiripan struktural secara keseluruhan terlihat pada tabel 2 .

TABEL II. PERHITUngan JACCARD SELURUH Model PRoses

\begin{tabular}{|c|c|c|c|c|}
\hline \multirow{2}{*}{ Figur } & \multicolumn{4}{|c|}{ Model Skenario } \\
\cline { 2 - 5 } & Sequence & Percabangan & $\begin{array}{c}\text { Percabangan } \\
\text { Tersarang }\end{array}$ & Looping \\
\hline A-B & 0.76 & 0.55 & 0.89 & 0.61 \\
\hline A-C & 0.50 & 0.61 & 0.82 & 0.75 \\
\hline B-C & 0.65 & 0.63 & 0.81 & 0.62 \\
\hline
\end{tabular}

Melalui perhitungan pada tabel 1 diatas, jika nilai kemiripan sama dengan 0 , berarti dua model yang telah dibandingkan memiliki perbedaan yang signifikan dan kurang memiliki keterhubungan. Begitu pula sebaliknya, jika nilainya sama dengan 1 , berarti dua model memiliki kesamaan maksimum.

Setelah mengukur kemiripan struktural, maka langkah selanjutnya adalah mengukur kemiripan perilakunya. Pengukuran kemiripan perilaku dilakukan untuk mendapatkan common fragment dari model proses dengan menggunakan algoritma TARs. Peneliti melambangkan gateway XOR yang terdapat dalam model proses dengan $\mathrm{X}$ pada TARset. Tabel 3 menunjukkan data TARset dari skenario model 3.

TABEL III. TARSET PERCABNGAN TERSARANG

\begin{tabular}{|l|l|c|}
\hline & \multicolumn{1}{|c|}{ TARset } & Jumlah \\
\hline Model A & $\begin{array}{l}\text { AX XB XC XD BX XE XF EX FX XX } \\
\text { CX DX XG XH XI GX HX IX XX XJ JK } \\
\text { KL }\end{array}$ & 22 \\
\hline Model B & $\begin{array}{l}\text { AX XB XC XD BX XE XF EX FX XX } \\
\text { CX DX XG XH XI XJ GX HX IX JX XX } \\
\text { XK KL }\end{array}$ & 23 \\
\hline Model C & $\begin{array}{l}\text { AX XB XC XD BX XE XF XG EX FX } \\
\text { GX XX CX DX XH XI HX IX XX XJ JK }\end{array}$ & 21 \\
\hline
\end{tabular}

Data TARset pada tabel 3 kemudian dimasukkan kedalam perhitungan kemiripan perilaku dengan menggunakan persamaan pada (2).

$$
\operatorname{sim} B=\frac{(20)^{2}}{22 \times 23}=\frac{400}{506}=0.79
$$

Dari perhitungan diatas, didapatkan nilai similaritas perilaku pada model 3A dan 3B sebesar 0.79. Kemudian, dengan langkah yang sama, dilakukan pengukuran kemiripan perilaku pada semua skenario menggunakan data TARset keseluruhan model proses yang ditunjukkan pada tabel 5. Nilai pengukuran TARs semua model proses ditunjukkan pada tabel 4 berikut.

TABEL IV. PENGUKURAN TARS KESELURUH MODEL PROSES

\begin{tabular}{|c|c|c|c|c|}
\hline \multirow{2}{*}{ Figur } & \multicolumn{4}{|c|}{ Model Skenario } \\
\cline { 2 - 5 } & Sequence & Percabangan & $\begin{array}{c}\text { Percabangan } \\
\text { Tersarang }\end{array}$ & Looping \\
\hline A-B & 0.67 & 0.25 & 0.79 & 0.19 \\
\hline A-C & 0.36 & 0.21 & 0.86 & 0.35 \\
\hline B-C & 0.24 & 0.30 & 0.82 & 0.27 \\
\hline
\end{tabular}

Data TARset untuk skenario model proses lainnya ditunjukkan pada tabel 5 berikut.

\begin{tabular}{|c|c|c|c|}
\hline \multicolumn{2}{|c|}{ Model Proses } & \multirow[b]{2}{*}{ AB BC CD DE } & \multirow{2}{*}{$\frac{\text { Jumlah }}{4}$} \\
\hline Sequence & A & & \\
\hline & B & AB BC CD DE EF FG & 6 \\
\hline & $\mathrm{C}$ & $\begin{array}{l}\text { AB BC CD DE EF FX XG XH GX } \\
\text { HX XI }\end{array}$ & 11 \\
\hline \multirow[t]{3}{*}{ Percabangan } & A & $\begin{array}{l}\text { AX XB XC XD BX CX DX XE EX } \\
\text { XF XG FX GX XH }\end{array}$ & 14 \\
\hline & B & $\begin{array}{l}\text { AB BC CX XD XE XF DX EX FX } \\
\text { XG }\end{array}$ & 10 \\
\hline & $\mathrm{C}$ & $\begin{array}{l}\text { AX XB XC XD XE BX CX DX EX } \\
\text { XF FG GH }\end{array}$ & 12 \\
\hline \multirow[t]{3}{*}{$\begin{array}{l}\text { Percabangan } \\
\text { Tersarang }\end{array}$} & A & $\begin{array}{l}\text { AX XB XC XD BX XE XF EX FX } \\
\text { XX CX DX XG XH XI GX HX IX } \\
\text { XX XJ JK KL }\end{array}$ & 22 \\
\hline & $\mathrm{B}$ & $\begin{array}{l}\text { AX XB XC XD BX XE XF EX FX } \\
\text { XX CX DX XG XH XI XJ GX HX } \\
\text { IX JX XX XK KL }\end{array}$ & 23 \\
\hline & $\mathrm{C}$ & $\begin{array}{l}\text { AX XB XC XD BX XE XF XG EX } \\
\text { FX GX XX CX DX XH XI HX IX } \\
\text { XX XJ JK }\end{array}$ & 21 \\
\hline \multirow[t]{3}{*}{ Looping } & A & $\begin{array}{l}\text { AX XB XC BX CX XD DE EF FG } \\
\text { GH }\end{array}$ & 10 \\
\hline & $\mathrm{B}$ & $\begin{array}{l}\text { AX XB XC BX CX XD DE EX XF } \\
\text { XG FX GX XH }\end{array}$ & 13 \\
\hline & $\mathrm{C}$ & AX XB XC BX CX XD DE & 7 \\
\hline
\end{tabular}

TABEL V. TARSET KESELURUHAN MODEL PROSES 
Untuk mengekstraksi common fragment, kita harus menentukan TARset yang sama dari model 3A sampai dengan Model 3C. TARset pada model 3A dibandingkan dengan model $3 \mathrm{~B}$ untuk mendapatkan fragmen dari kedua model tersebut. Hal yang sama dilakukan pada TARset model 3A dengan 3C serta 3B dengan 3C, sehingga dapat ditemukan fragmen yang sama dari ketiga model. Fragmen yang sama tersebut ditunjukkan dengan warna merah seperti pada tabel 6. Fragmen yang sama dari ketiga model merupakan hasil ekstraksi untuk scenario 3.

TABEL VI. COMmon FRagment PERCABANGAN TeRsarang

\begin{tabular}{|c|l|}
\hline & \multicolumn{1}{|c|}{ TARset } \\
\hline Model A & $\begin{array}{l}\text { AX XB XC XD BX XE XF EX FX XX CX DX XG } \\
\text { XH XI GX HX IX XX XJ JK KL }\end{array}$ \\
\hline Model B & $\begin{array}{l}\text { AX XB XC XD BX XE XF EX FX XX CX DX XG } \\
\text { XH XI XJ GX HX IX JX XX XK KL }\end{array}$ \\
\hline Model C & $\begin{array}{l}\text { AX XB XC XD BX XE XF XG EX FX GX XX CX } \\
\text { DX XH XI HX IX XX XJ JK }\end{array}$ \\
\hline $\begin{array}{c}\text { Hasil } \\
\text { Ekstraksi }\end{array}$ & $\begin{array}{l}\text { AX XB XC XD BX XE XF XG EX FX GX XX CX } \\
\text { DX XH XI HX IX XX XJ }\end{array}$ \\
\hline
\end{tabular}

Untuk skenario model proses lainnya, data TARset pada tabel 5 dibandingkan dan dicari kesamaannya seperti pada tabel 6 untuk diekstraksi fragmen yang sama. Hasil ekstraksi common fragment pada setiap skenario model proses terdapat pada tabel 7.

TABEL VII. COMmon FRAGMENT SELURUH MOdEL Proses

\begin{tabular}{|l|l|}
\hline \multicolumn{1}{|c|}{ Model Proses } & \multicolumn{1}{c|}{ Common Fragment } \\
\hline Sequence & AB BC CD DE \\
\hline Percabangan & CX XD XE DX EX XF \\
\hline $\begin{array}{l}\text { Percabangan } \\
\text { Tersarang }\end{array}$ & $\begin{array}{l}\text { AX XB XC XD BX XE XF XG EX FX GX XX } \\
\text { CX DX XH XI HX IX XX XJ }\end{array}$ \\
\hline Looping & AX XB XC BX CX XD DE \\
\hline
\end{tabular}

Setelah ekstraksi common fragment, kami mendapatkan TARset untuk menjadi common fragment dari masingmasing skenario model proses bisnis. Proses ini akan membentuk model jaring BPMN baru seperti terdapat pada tabel 8 .

TABEL VIII. COMMON PROCESS SELURUH MODEL PRoseS

\begin{tabular}{|c|c|}
\hline $\begin{array}{c}\text { Model } \\
\text { Proses }\end{array}$ & Common Process \\
\hline Sequence & $\bigcirc \rightarrow \mathrm{A} \rightarrow \mathrm{B} \rightarrow \mathrm{C} \rightarrow \mathrm{D} \rightarrow \mathrm{B} \rightarrow$ \\
\hline
\end{tabular}

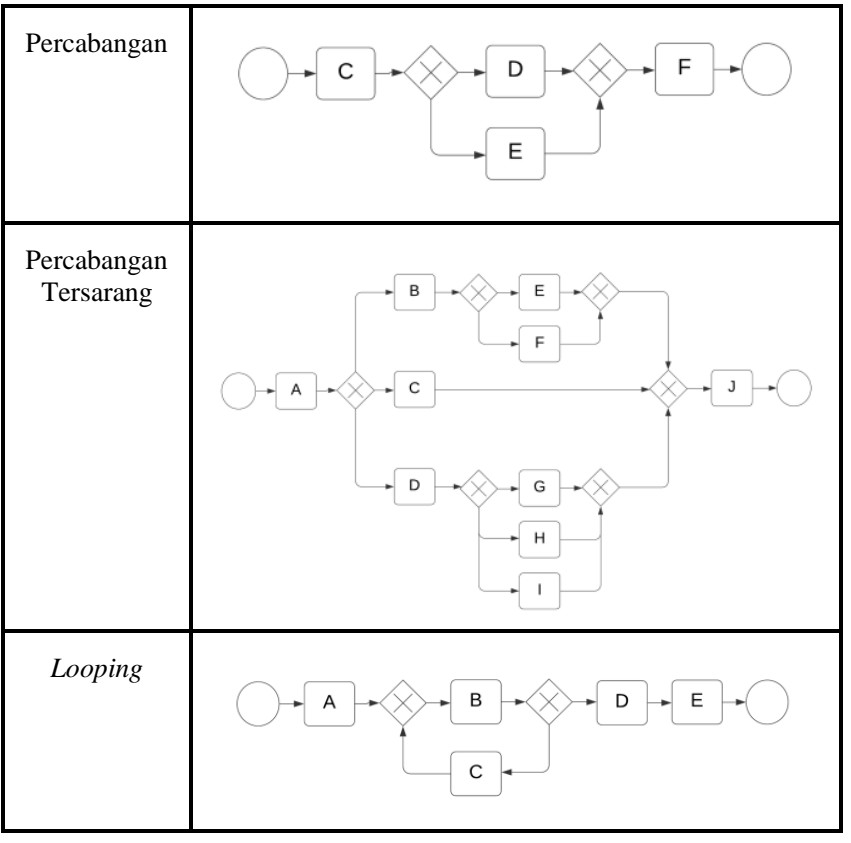

Berdasarkan tabel tersebut, model proses dengan percabangan tersarang akan menghasilkan common process dengan struktur yang cenderung sama juga yaitu, memiliki banyak percabangan dan di dalam percabangan tersebut terdapat percabangan lagi seperti ditunjukkan pada Gambar. 6.

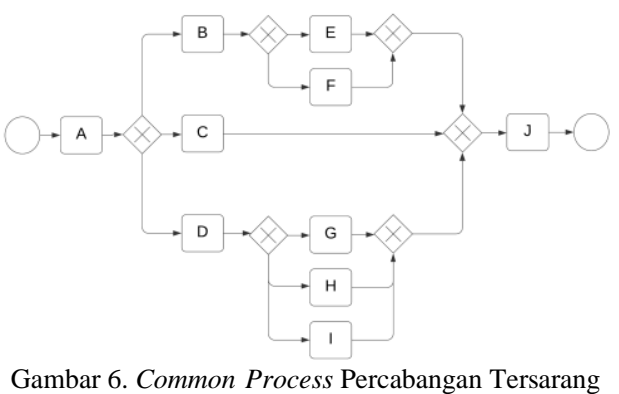

Model proses cenderung sequence menghasilkan common process dengan struktur yang sama pula. Model proses percabangan menghasilkan common process dengan struktur yang sama yakni, terdapat percabangan. Model proses perulangan menghasilkan common process dengan struktur yang mengandung unsur perulangan juga.

Kami kemudian melakukan perhitungan kompleksitas dari model proses bisnis lama dan model proses bisnis baru. Perhitungan kompleksitas dilakukan untuk mendapatkan nilai persentase terhadap penyusutan jumlah elemen. berikut perhitungan menggunakan (3) pada skenario model 3.

Model 3A

$\mathrm{YC}=18+24+18+29.16$

$$
=89.16
$$

Model 3B

$$
\begin{aligned}
\mathrm{YC} & =18+24+21+31.5 \\
& =94.5
\end{aligned}
$$

Model 3C 
YC

$$
\begin{aligned}
& =16+21+15+29.4 \\
& =81.4
\end{aligned}
$$

Model 3CP

$$
\begin{aligned}
\mathrm{YC} & =16+22+18+32.2 \\
& =88.2
\end{aligned}
$$

Persentase Penyusutan $=\frac{\text { nilai bagian }}{\text { nilai keseluruhan }} \times 100$

$$
\begin{aligned}
& =\frac{88.2}{265.6} \times 100 \\
& =33.2 \%
\end{aligned}
$$

\begin{tabular}{|c|c|c|c|c|c|}
\hline \multirow[t]{2}{*}{ Model Proses } & \multicolumn{4}{|c|}{ Complexity } & \multirow{2}{*}{$\begin{array}{l}\text { Persentase } \\
\text { Penyusutan }\end{array}$} \\
\hline & $\mathbf{A}$ & B & $\mathbf{C}$ & $\mathbf{C P}^{*}$ & \\
\hline Sequence & 27 & 31 & 48.8 & 27 & $25.3 \%$ \\
\hline Percabangan & 68.75 & 52 & 60.22 & 43 & $22.5 \%$ \\
\hline $\begin{array}{c}\text { Percabangan } \\
\text { Tersarang }\end{array}$ & 89.16 & 94.5 & 81.4 & 88.2 & $33.2 \%$ \\
\hline Looping & 54 & 47.5 & 43.6 & 43.6 & $30 \%$ \\
\hline
\end{tabular}

Perhitungan persentase penyusutan terhadap jumlah elemen pada model proses awal dan common process disajikan pada TABEL IX.

TABEL IX. PERSENTASE PENyUSUTAN

Setelah dilakukan perbandingan elemen seperti pada tabel 9, terlihat bahwa terjadi penyusutan terhadap jumlah elemen BPMN pada setiap model proses. Model proses percabangan tersarang mengalami penyusutan paling besar yakni, 33.2\% sedangkan penyusutan paling kecil terdapat pada model proses percabangan dengan $22.5 \%$.

\section{KESIMPULAN}

Dari hasil percobaan yang telah dilakukan, didapatkan hasil bahwa Algoritma Jaccard Coefficient dapat menunjukkan kemiripan struktural pada model BPMN yang digunakan dengan hasil pengukuran mendekati nilai 1, yang artinya model memiliki kesamaan hampir maksimum secara struktural. Common fragment didapatkan dengan dengan mengukur kemiripan perilaku model proses menggunakan algoritma Transition Adjacency Relations (TARs). Common fragment tersebut merupakan prosedur yang sama yang dapat diterapkan dalam lingkungan organisasi sesuai kondisi yang diinginkan tanpa mengubah proses bisnis yang bersifat personal. Hasil ekstraksi common fragment menunjukkan model proses cenderung sequence menghasilkan common process yang cenderung sequence pula. Model proses cenderung bercabang, menghasilkan common process yang memiliki percabangan pula. Model proses percabangan tersarang menghasilkan common process yang mengandung percabangan tersarang pula. Terakhir, model proses perulangan menghasilkan common process yang mengandung unsur perulangan pula. Pengukuran penyusutan jumlah elemen dari model proses bisnis lama dan model proses bisnis baru diukur menggunakan Yaqin complexity. Berdasarkan hasil eksperiman kami, didapati bahwa model proses percabangan tersarang mengalami penyusutan paling besar yakni, 33.2\% sedangkan penyusutan paling kecil terdapat pada model proses percabangan dengan $22.5 \%$.

\section{REFERENSI}

[1] R. Sarno, E. W. Pamungkas, D. Sunaryono, and Sarwosri, "Workflow common fragments extraction based on WSDL similarity and graph dependency," in 2015 International Seminar on Intelligent Technology and Its Applications (ISITIA), 2015, pp. 309-314.

[2] A. C. Fauzan, R. Sarno, M. A. Yaqin, and A. Jamal, "Extracting common fragment based on behavioral similarity using transition adjacency relations for scalable business processes," in 2017 11th International Conference on Information \& Communication Technology and System (ICTS), 2017, pp. 131-136.

[3] M. A. Yaqin and G. U. Abriania, "Implementasi Metode Semantic Similarity untuk Pengukuran Kemiripan Makna antar Kalimat," J. Comput. Sci. Appl. Informatics, vol. 1, no. 2, pp. 47-57, 2019.

[4] A. P. Wahyu, M. A. Yaqin, and S. Zaman, "Common Process Extraction Pada Scalable Model Proses Bisnis,” Konf. Nas. Sist. Inf. 2018, pp. 1-6, 2018.

[5] R. Dijkman, M. Dumas, and L. García-Bañuelos, "Graph matching algorithms for business process model similarity search," Lect. Notes Comput. Sci., vol. 5701, pp. 48-63, 2009.

[6] S. Niwattanakul, J. Singthongchai, E. Naenudorn, and S. Wanapu, "Using of jaccard coefficient for keywords similarity," in Proceedings of the International MultiConference of Engineering and Computer Scientists 2013, 2013, vol. 1, pp. 13-15.

[7] M. A. Yaqin, R. Sarno, and S. Rochimah, "Measuring Scalable Business Process Model Complexity Based on Basic Control Structure,” Int. J. Intell. Eng. Syst., vol. 13, no. 6, pp. 52-65, 2020.

[8] M. A. Yaqin, R. Sarno, and A. C. Fauzan, "Scalability measurement of business process model using business processes similarity and complexity," in 2017 4th International Conference on Electrical Engineering, Computer Science and Informatics (EECSI), 2017, pp. $1-7$. 